University of Wollongong

Research Online

Faculty of Business - Papers (Archive)

Faculty of Business and Law

$1-1-2019$

Financial liberalisation, bank ownership type and performance in a transition economy: The case of Vietnam

Phuong Le

Ton Duc Thang University, tpl375@uowmail.edu.au

Charles Harvie

University of Wollongong, charvie@uow.edu.au

Amir Arjomandi

University of Wollongong, amira@uow.edu.au

James Borthwick

University of Wollongong, jamesbor@uow.edu.au

Follow this and additional works at: https://ro.uow.edu.au/buspapers

Part of the Business Commons

Research Online is the open access institutional repository for the University of Wollongong. For further information contact the UOW Library: research-pubs@uow.edu.au 


\title{
Financial liberalisation, bank ownership type and performance in a transition economy: The case of Vietnam
}

\author{
Abstract \\ Employing a sample of Vietnamese banks covering the period 2005 to 2015 , this study investigates the \\ influence of partial, and selective, financial liberalisation on bank efficiency by ownership type in a \\ transition economy. The key findings are: (1) state-owned banks outperformed all other ownership types; \\ (2) selective privatisation of state-owned banks exerted a positive influence on bank efficiency; (3) rural- \\ to-urban private bank transformation decreased banking system efficiency; (4) minority foreign ownership \\ exerted an insignificant impact on bank efficiency; (5) business group ownership improved the provision \\ of intermediation services but deteriorated overall bank operating efficiency. Overall, the findings suggest \\ that the post-WTO partial-liberalisation of the banking system in Vietnam impacted banks' efficiency \\ differently subject to ownership type, with potentially adverse implications for long term economic growth \\ and development.

\section{Disciplines \\ Business}

\section{Publication Details} \\ Le, P. Thanh., Harvie, C., Arjomandi, A. \& Borthwick, J. (2019). Financial liberalisation, bank ownership type \\ and performance in a transition economy: The case of Vietnam. Pacific-Basin Finance Journal, 57 \\ 101182-1-101182-17.
}


1 Financial liberalisation, bank ownership type and performance in a transition economy: the case of Vietnam

\section{Abstract}

4 Employing a sample of Vietnamese banks covering the period 2005 to 2015, this study

5 investigates the influence of partial, and selective, financial liberalisation on bank efficiency

6 by ownership type in a transition economy. The key findings are: (1) state-owned banks

7 outperformed all other ownership types; (2) selective privatisation of state-owned banks

8 exerted a positive influence on bank efficiency; (3) rural-to-urban private bank

9 transformation decreased banking system efficiency; (4) minority foreign ownership exerted an insignificant impact on bank efficiency; (5) business group ownership improved the provision of intermediation services but deteriorated overall bank operating efficiency.

Overall, the findings suggest that the post-WTO partial-liberalisation of the banking system in Vietnam impacted banks’ efficiency differently subject to ownership type, with potentially adverse implications for long term economic growth and development.

JEL Classifications: D24, G21

Keywords: bank efficiency; financial liberalisation; ownership type; business environment; Vietnam; data envelopment analysis; generalised difference-in-differences.

\section{Introduction}

Transition towards market oriented economies by the formerly centrally planned European and Asian nations in the late 1980s and early 1990s triggered the adoption of economic liberalisation policies. Foremost among these was financial liberalisation focused on transforming state dominated banking systems from single to two-tier structures. This increased competition and transformed state to private ownership in the sector. Banking system liberalisation, however, varied among transition economies in terms of both scope of coverage and speed of implementation. Generally, two broad approaches emerged. The first 
involved full liberalisation without limits with all banks treated equally regardless of ownership (public, private and foreign). Publicly-owned banks no longer dominated the market nor were they used as vehicles for the enactment of state policies. This type of liberalisation (the so-called 'big bang' approach) was adopted in many of the former transition countries of Central and Eastern Europe, where transformation to a competitive and primarily privately controlled banking sector has largely been implemented (Bonin et al., 2005a; 2005b; Fries and Taci, 2005; Havrylchyk, 2006; Kraft et al., 2006; Karas et al., 2010; Bonin and Schnabel, 2011). The second approach involved gradual and incremental liberalisation, where state-owned banks remained as dominant players and key policy facilitators, while retaining competitive advantages in terms of implicit government guarantees, less risk and access to cheaper funding. A gradual liberalisation approach has been prevalent in the banking systems of countries such as China, Russia and Vietnam.

The aim of this study is to evaluate the impact of the gradual or incremental approach to banking sector reform adopted by Vietnam on the efficiency of various categories of banks based on their ownership type. Improving banking sector efficiency is critical for the promotion of economic growth in countries with a predominantly bank-based financial system, as is the case in Vietnam (Hasan et al., 2009; Koetter and Wedow, 2010). For transition economies more generally, Koivu (2002) provides evidence to suggest that banking sector efficiency is particularly important in facilitating economic growth in transition countries. Evidence as to which type of bank ownership best drives efficiency is, however, mixed. Levine (2001) argues that economic growth is most effectively achieved through international financial liberalisation that enables foreign banks greater access to the domestic market, while La Porta et al. (2002) argue that state ownership of banks slows financial development. On the other hand, Andrianova et al. (2012) argue that long run economic growth is improved by government ownership of banks. The discriminatory nature of the 
banking reforms adopted in Vietnam, specifically against domestic private and foreignowned banks, and the resulting banking sector distortions and inefficiencies, has the potential, therefore, to adversely impact the future growth and development of the economy.

The structure of the paper is as follows. Section 2 reviews the Vietnamese banking sector after the abandonment of central planning and adoption of market oriented reform measures. Section 3 provides an overview of the banking efficiency-ownership type literature for the case of transition economies. The bank efficiency measurement methodology adopted, including data envelopment analysis (DEA) and double bootstrap DEA, is presented in Section 4. Section 5 describes the data and specifies inputs/outputs. Section 6 describes the explanatory variables used in the regression models and presents an analysis of the empirical results, while Section 7 highlights key findings and policy implications.

\section{The Vietnamese banking sector}

At its sixth National Congress in December 1986, the Communist Party of Vietnam made a decisive step to abandon central planning and adopt, instead, a socialist market-oriented system. This became known as 'Doi Moi’ (renovation) (Harvie and Hoa, 1997; Beresford, 2008). Accordingly, the mono-bank system, which only served the needs and demands of the state sector, was split into a two-tier banking system with the State Bank of Vietnam (SBV) playing the key role of central bank on one tier and state-owned commercial banks (SOCBs) as lenders on the other. The new system also permitted the entry of private banks in the form of joint-stock banks (JSBs) and a limited presence of overseas investors in joint-venture banks. The JSBs faced many difficulties not only in terms of financial capacity but also in terms of managerial capability. During the 1990s a large proportion of SOCB loans were allocated to inefficiently operating SOEs; a legacy of the period of central planning which continues to persist today (Oh, 1999; Beresford, 2008; World Bank, 2014). 
The East Asian Financial Crisis (EAFC), and its exposure of institutional and structural weaknesses, resulted in economic slowdown between 1998 and 2000, and provided further impetus for reform of the Vietnamese banking sector (Kovsted et al., 2005). Reform measures included: building a robust regulatory and supervisory framework; improving the quality of domestic banks, focusing especially on SOCBs through the separation of policy lending from commercial lending; writing off bad loans; bank recapitalisation, technical support and the enhancement of risk management strategies. Despite this series of reform measures, the banking sector remained largely 'off limits' to overseas investors. Indeed, during the pre-WTO entry period (i.e. pre 2007), overseas investors were only allowed to take part in the banking sector through a limited presence in joint-venture banks or through participation in a limited number of bank branches in Vietnam. Overseas investors were also not permitted to open 100 per cent foreign-owned banks or participate in domestic banks as shareholders. This was to change, however, as a requirement for Vietnam's entry into the WTO on 11 January 2007. The composition of the Vietnamese banking sector by different bank ownership types after WTO entry and up to December 2016 is summarised in Table 1.

\section{$<$ TABLE 1 ABOUT HERE $>$}

The entry of Vietnam into the WTO resulted in an increased presence of foreign banks from April 2007 and allowed wholly foreign-owned banks to participate in the banking sector (Pincus, 2009). These foreign banks were now allowed to receive deposits and lend in Vietnamese dong, but their operations remained largely confined to major commercial centres such as Ho Chi Minh City and Hanoi. This entry also prompted additional reforms aimed at enhancing the competitiveness and efficiency of domestic banks. Reforms included allowing for the partial privatisation of SOCBs and providing foreign investors with rights to purchase equity in domestic banks. Total foreign investment in Vietnamese joint-stock commercial banks, however, was limited to 30 per cent of each bank’s chartered capital. 
100 Opening the banking market to foreign investment generated concerns over the competitiveness of domestic banks. ${ }^{1}$ Both SOCBs and JSBs faced difficulties from low efficiency, out-of-date technology and limited capital. The government's 2006 Decree 141 increased the required minimum notional capital levels of all credit institutions (IMF, 2012; NAEC, 2012) with the objective of increasing domestic bank resources and size, stating that any commercial banks that could not conform to the stipulated levels by the end of 2010 would be forced to merge, reduce the scope of their activities, or have their bank licence revoked. As a result, all small domestic JSBs faced an uphill battle to increase their capital levels by up to 10 times in a five-year period (NAEC, 2012). Calling for equity participation from large banks, private business groups and SOEs became a logical source of funds which, as a consequence, resulted in numerous and complex cross-ownerships involving JSBs (IMF, 2012; NAEC, 2012). Most loans by these banks were subsequently allocated to related parties, rather than to the most profitable projects (Pincus, 2009; Nguyen et al., 2014). A lack of regulation relating to cross-ownership and the limited capability of supervisory departments worsened this situation. Under pressure from the need for all domestic banks to increase their capital capability, the SBV substantially loosened its regulations when permitting thirteen rural banks to transform into urban banks during the period 2006-2007 (NAEC, 2012). In 2005, the total capital of these banks was estimated at 165 billion Vietnamese dong (VND), or 13.75 billion VND on average for each bank. With the introduction of Decree 141, each urban bank had to achieve a chartered capital level of at least 1,000 billion VND by the end of 2008 and of at least 3,000 billion VND by the end of 2010.

\footnotetext{
${ }^{1}$ There was a general reluctance by the authorities to engage in banking sector liberalisation, particularly in terms of the privatisation of state-owned banks and the entry of foreign-owned banks. But these were conditions for entry into the WTO.
} 
Overall, the Vietnamese banking sector was significantly transformed by these reforms during the post-WTO entry period. As a result it is important to examine the effects of these reforms on bank efficiency performance while at the same time identifying any additional policy measures that could further improve bank efficiency in Vietnam.

\section{Literature review}

Findings in studies that employ stochastic frontier analysis (SFA) and DEA suggest that bank ownership type is a major determinant of bank efficiency in transition and emerging economies. Both cross country and single country approaches generally find that state-owned banks are the least efficient ownership type (see, for example, Jemric and Vujcic, 2002; Bonin et al., 2005a, 2005b; Fries and Taci, 2005; Grigorian and Manole, 2006) while the most efficient banks are foreign-owned (Hasan and Marton, 2003; Weill, 2003; and Bonin et al., 2005a). While cross country results tend to be quite uniform, single country studies often produce conflicting results (see Karas et al., 2010; Mamonov and Vernikov, 2017). Outcomes by ownership type can differ depending upon whether a cost or profit efficiency approach is adopted (Berger et al., 2000), as well as a country’s stage of development. Foreign banks in more developed countries are generally less cost efficient than domestic banks, while the converse holds for developing countries (see Berger et al., 2000; Hasan and Hunter, 1996; and Chang et al., 1998).

Major cross country efficiency studies focusing on Central and Eastern European Countries (CEECs) that engaged in a 'big bang' approach to banking reform, find that majority foreignowned banks are more cost efficient while government-owned banks are the least cost efficient (see, for example, Bonin et al., 2005a, 2005b; Fries and Taci, 2005; KoutsomanoliFilippaki et al., 2009; Yildirim and Philippatos, 2007; and Fang et al., 2011). Fries and Taci (2005) also find that while private banks are more cost efficient than state-owned banks, 
major differences exist between them. Privatised banks with majority foreign ownership were the most cost efficient, followed by newly established domestic and foreign-owned private banks. Privatised banks with majority domestic ownership were the least efficient of the private banks, with state-owned banks the least efficient of all. Similar results are presented in Grigorian and Manole (2006).

Single country efficiency studies find a generally superior performance by foreign-owned banks amongst CEECs. See, for example, Tochkov and Nenovsky (2009) for Bulgaria, Opiela (2000) and Nikiel and Opiela (2002) for Poland, Hasan and Marton (2000) for Hungary, Weill (2003) for the Czech Republic and Poland, and Jemric and Vujcic (2002) for Croatia. In contrast, Zajc (2006) finds that domestic banks were more cost-efficient than their foreign counterparts due to the latter either having higher start-up costs in a new market or from limited competition in the new market.

Two separate hypotheses have been advanced to explain these differences in efficiency outcomes based on ownership type. The global advantage hypothesis and the home field advantage hypothesis. The former postulates that foreign banks have superior managerial skills, corporate policies and procedures, and better investment and risk management skills; resulting in lower costs, increased profitability and risk diversity. The home field advantage hypothesis argues that domestic banks are relatively more cost efficient because they do not have to deal with the same set of issues facing foreign banks including implicit market barriers, managerial and monitoring challenges, cultural and language differences and the complexity associated with negotiating foreign market regulation and supervisory arrangements (Belousova et al., 2018). Foreign banks face greater set-up costs in a new market and implicit and explicit discrimination that lowers their cost efficiency. A further dimension to the home field advantage hypothesis, and of direct relevance to this study, is that state-owned and domestic banks in emerging or transition economies may operate in an 
environment that provides them with a distinct competitive advantage due to government implicit guarantees and access to lower cost funding (Karas et al., 2010; Vernikov, 2012). In addition, state-owned banks may benefit from discriminatory policy measures aimed at maintaining their size and dominance in the domestic market for political reasons.

Country-specific results for transition countries adopting a more gradual and selective approach to bank reform, such as for Russia and China, have produced contradictory results for the cost efficiency of foreign, domestic private and state-owned banks. Karas et al. (2010) and Styrin (2005) find support for the global advantage hypothesis amongst Russian banks. For example, Karas et al. (2010) show that foreign banks were more cost efficient than domestic private banks due to their advanced banking technology and superior riskmanagement and state-owned banks were comparable with domestic banks in terms of cost efficiency. Belousova et al. (2018) find that foreign-owned banks were the most profit efficient in Russia, followed by state-owned banks and private domestic banks.

In contrast, Vernikov (2012) finds that due to government connections, state-owned Russian banks were more profitable and efficient relative to private and foreign-owned equivalents. Mamonov and Vernikov (2017) and Golovan et al. (2008) also find support for the home field advantage hypothesis for Russian banks with key state-owned banks being nearly as efficient as private domestic banks. Foreign-owned banks often have to create infrastructure and branch networks from scratch, recruit staff, attract clients, and build long-term relations, all of which reduce their cost and profit efficiency. In comparison, domestic and state-owned banks exhibit greater cost and profit efficiency due to their connections with government.

Berger et al., (2009) examined the effect of partial and selective bank liberalisation in China from 1994 to 2003. The Big Four state-owned banks were found to be the least efficient, foreign banks the most efficient, and minority foreign ownership was associated with 
significantly improved efficiency. Similar conclusions on the superior efficiency of private domestic and foreign-owned banks to that of state-owned banks was found by Zhang and Wang (2014), Xu (2011), Leung and Chan (2006) and Chen and Wang (2015). These studies provide evidence of the global advantage hypothesis operating in the Chinese banking sector, despite the close connection between major state-owned banks and the government.

Unlike the gradual (partial) and selective liberalisation of banking systems approach adopted in Russia and China, the effects of such an approach on bank efficiency by ownership type has yet to be examined for Vietnam. Banking reform in Vietnam can be characterised as sluggish towards bank privatisation and unfriendly towards foreign investment. Hence, the home field advantage hypothesis could still be prevalent in Vietnam, and the effects of this on bank efficiency by ownership type have until now not been adequately analysed. As a 'fundsstarved' developing country, access to, and efficient allocation of, available funds through an efficient banking system is critical for its future economic development (Berger et al., 2009). The focus of this study is to identify whether Vietnam's approach to bank reform following its entry into the WTO improved or diminished banking efficiency based on ownership type.

\section{Methodology}

This section outlines the methodology adopted in this paper to measure the technical efficiency of Vietnamese banks by ownership type covering the period 2005-2015. The following two sub-sections describe the methods used in this study for estimating technical efficiency and exploring possible determinants of bank efficiency in Vietnam, respectively.

\subsection{Measuring technical efficiency}

Consider an industry consisting of $N$ firms (here: banks) operating through $\mathrm{T}$ years. By pooling available data we can obtain $n$ bank-year observations $(k=1, \ldots, n)$. Each bank employs $p$ inputs to produce $q$ outputs. Let $x \in \mathbb{R}_{+}^{p}$ denote a vector of $p$ inputs and $y \in \mathbb{R}_{+}^{q}$ 
be defined by:

$\wp=\left\{(x, y) \in \mathbb{R}_{+}^{p} \times \mathbb{R}_{+}^{q}: x\right.$ can produce $\left.y\right\}$

We use the Farrell (1957) measure of output-oriented technical efficiency, defined by:

$\delta(x, y \in \wp) \equiv \max \{\delta /(x, \delta y) \in \wp, \delta \geq 1\}$

Under the assumption of free disposability of inputs and outputs and variable returns to scale, the DEA representation of the production set is: ${ }^{2}$

$\widehat{\wp}=\left\{(x, y) \in \mathbb{R}_{+}^{p} \times \mathbb{R}_{+}^{q}: \sum_{k=1}^{n} z_{k} y_{k}^{i} \geq y^{i}, i=1, \ldots, q ; \sum_{k=1}^{n} z_{k} x_{k}^{j} \leq x^{j}, j=\right.$ $\left.1, \ldots, p ; \sum_{k=1}^{n} z_{k}=1, z_{k} \geq 0, k=1, \ldots, n\right\}$

Farrell's measure of technical efficiency $(\delta)$ is the reciprocal of the Shephard distance

first stage by solving the following model:

$\hat{\delta}=\operatorname{Max} \delta$

Subject to:

$$
\sum_{k=1}^{n} z_{k} y_{k}^{i} \geq \delta y^{i}, i=1, \ldots, q ;
$$$$
\sum_{k=1}^{n} z_{k} x_{k}^{j} \leq x^{j}, j=1, \ldots, p \text {; }
$$$$
\sum_{k=1}^{n} z_{k}=1
$$

$$
z_{k} \geq 0, k=1, \ldots, n
$$

\footnotetext{
${ }^{2}$ The constant-returns-to-scale assumption is only appropriate when all firms are operating at their optimal scale (Charnes et al., 1978). In the banking sector banks are strongly impacted by regulations imposed by central banks, such as those on capital adequacy and loan-loss provisioning. In addition, in the case of Vietnam, private banks are discriminated against relative to state-owned banks, causing an imperfect business environment among different bank groups. Consequently, Vietnamese banks may not perform at their optimal scale. Hence, this research chooses the assumption of variable returns to scale when measuring the technical efficiency of Vietnamese banks.
} 
237 To analyse the possible factors influencing technical efficiency we utilise the Simar and

238 Wilson (2007) method as discussed in the following sub-section.

239

240

241

242

\subsection{Double bootstrap DEA}

Regressing the estimated DEA efficiency $(\hat{\delta})$ against a group of explanatory variables in the second stage can be conducted using several estimation techniques such as OLS or Tobit regression. There are, however, serious problems raised in the literature regarding the use of the OLS and Tobit methods (Simar and Wilson, 2007). One issue is that the DEA estimates which are based on a finite sample are downward-biased (Simar and Wilson, 1998; Kneip et al., 1998; 2008). This is because the 'best practice' observations in the sample are employed to construct the production frontier rather than true efficient (but unobservable) observations. This means that coefficients derived from the second stage can be biased as well. It is also shown by Simar and Wilson (2007) that DEA efficiency scores are expected to be correlated with each other because the calculation of one firm's efficiency incorporates the observations of all other firms in the same data set. Hence, direct regression analysis can also be invalid due to the dependency of the efficiency scores. In order to avoid these problems the double bootstrap DEA model of Simar and Wilson (2007) is used in this study to regress inefficiency scores against ownership indicators, policy-change indicators, bank characteristics and a time trend. In their proposed double bootstrap procedure, DEA bias corrected scores can then be used in a parametric bootstrap on the truncated maximum likelihood estimation. Confidence intervals can then be constructed for the regression parameters and the efficiency scores.

Formally, a model regressing true inefficiency scores on environmental variables is described as: $\delta_{k}=z_{k} \beta+\varepsilon_{k} \geq 1$

where $z_{k}$ is a vector of explanatory variables for each bank-year observation $(k=1, \ldots, n)$, including a constant term, that are expected to influence the efficiency of banks under 
consideration and $\beta$ is a vector of parameters with some statistical noise $\varepsilon_{k}$. The true inefficiency scores $\left(\delta_{k}\right)$ are unobservable and are replaced by DEA estimates from the first stage. $^{3}$

\section{Data and specification of inputs and outputs}

\subsection{Data source}

All four commercial bank ownership types in Vietnam are accounted for in this study: stateowned commercial banks (SOCBs), joint-stock banks (JSBs), joint-venture banks (JVBs) and foreign-owned banks (FBs). ${ }^{4}$ However, because both FBs and JVBs contribute approximately 10 per cent of banking assets in Vietnam (see Table 1), and are mostly or totally owned by foreigners, we classify them together in a group called foreign and joint-venture banks (FJVBs). Consequently, there are three bank ownership groups that we consider for empirical analysis: SOCBs, JSBs, and FJVBs. With respect to SOCBs, although several have been privatised and their equity sold to foreign and domestic private investors, most of these banks are still majority state-owned. JSBs are banks where the majority of ownership is held by private entities or SOEs, and where foreign ownership is capped at 30 per cent of total equity. The two bank ownership types which form the FJVB group in this study include JVBs and FBs. JVBs are normally established by an SOCB with one or more foreign counterparts where the foreign investors own at least half of the bank capital. FBs are banks where total capital is contributed to by foreign investors. Annual data on different bank ownership types for the period 2005 to 2015 was collected and pooled from financial statements; generating an unbalanced panel consisting of 317 observations. Due to the small sample size the sample

\footnotetext{
${ }^{3}$ For a more detailed description of the double bootstrap approach used in this study, see Algorithm 2 of Simar and Wilson (2007, p.42) which is provided in Appendix A. This Algorithm was conducted using MATLAB codes provided by Associate Professor Valentine Zelenyuk, University of Queensland, Australia. The programming codes are not reported in this paper due to confidentiality requirements.

${ }^{4}$ See Table 1.
} 
was pooled in order to overcome issues associated with a lack of statistical power (Salim et al., 2017).

\subsection{Inputs and outputs}

The intermediation and operating approaches are employed in this study to define bank inputs and outputs. Both approaches are widely used in the banking literature (Jiang et al., 2009; Arjomandi et al., 2014; Rosman et al., 2014; Belanès et al., 2015; Chiu et al., 2016; Salim et al., 2016). Under the intermediation approach, banks are seen as financial institutions whose primary modus operandi is the intermediation of funds between savers and borrowers (Rosman et al., 2014; Belanès et al., 2015; Chiu et al., 2016). The common inputs for this approach are labour expenditure, fixed assets and deposits while the outputs are loans and non-traditional assets, including trading securities and investments. These inputs and outputs are similarly employed in this study. Intermediation technical efficiency indicates the servicerelated performance of a bank in terms of providing loans and advances to their customers relative to other banks. It is the most commonly adopted approach used in existing studies to establish the technical efficiency of Vietnamese banks (see, for example, Nguyen, 2007; Nguyen et al., 2012; 2014).

The operating approach (or profit-oriented approach) views banks as decision-making units that direct their efforts towards the maximisation of profit (Leightner and Lovell, 1998). Berger and Mester (2003, p.80) state that the use of the operating approach "may help take into account unmeasured changes in the quality of banking services by including higher revenues paid for the improved quality, and may help capture the profit maximization goal by including both the costs and revenues”. This approach considers interest and non-interest income as a bank's main outputs and defines interest and non-interest expenses as inputs. There is a consensus in the literature regarding the selection of these variables for analysing the operating (profit-oriented) efficiency of banks (Jiang et al., 2009; Arjomandi et al., 2014; 
Salim et al., 2016). While used commonly in the literature this approach has not been considered in similar previous studies of Vietnamese banks. Both the intermediation and operating approaches are adopted in this study to help us better understand, and have a more complete picture, of the performance of Vietnamese banks from the perspective of both service-provision and profit-maximisation.

\section{Empirical analysis and results}

The empirical results are divided into a series of sub-sections. Section 6.1 presents an overview of the estimated original and bias-corrected efficiency scores. Sections 6.2 and 6.3 detail the specification of the primary regression model and results. The remainder of the section presents the results from a generalised difference-in-differences model of the relationship. Section 6.4 provides the justification for the use of this model and section 6.5 presents the results. Section 6.4 and 6.5 are included as means of addressing potential endogeneity concerns associated with self-selection and omitted variable bias when considering the influence of policy changes on bank efficiency.

\subsection{Results for conventional and bootstrap DEA measures of bank efficiency}

The estimated 95\% confidence intervals for technical efficiencies under the intermediation and operating approaches are shown in Figures 1 and 2, respectively. The figures show the pooled sample observations (for the sample period of 2005-2015) ordered by values of the bias-corrected efficiencies. The bias-corrected efficiency scores (shown as Bias cor.) and the intervals presented in the figures are estimated using the bootstrap procedure with 2000 replications. The confidence interval boundaries are shown by solid lines. As can be seen in the figures, the original efficiencies (Orig. eff.) are not included in the confidence intervals and lie just below the lower boundary; reflecting the theory behind the construction of these confidence intervals (Simar and Wilson, 1998). It is also apparent from the figures that bank 
efficiency ranking based on bias-corrected efficiencies is in many cases different from that derived from the original efficiencies. In particular, the most efficient banks (with Orig. eff. = 1) showed more dramatic deteriorations in the bias-corrected efficiencies in both figures. This issue is more noticeable under the intermediation approach. Overall, the results highlight the importance of using the bootstrapping method and bias-corrected estimates instead of the original scores. In the following sub-sections, regression variables used in this study are described followed by the empirical results.

\section{$<$ FIGURES 1 AND 2 ABOUT HERE $>$}

\subsection{Specification of the regression model}

Intermediation technical efficiency (ITE) and operating technical efficiency (OTE) are used as bank performance measures in two different regressions. The independent variables are classified into three main types: ownership indicators, policy-change indicators and control variables. The control variables include bank-specific and time-trend variables. The model can be presented as: Bank performance measure $=\gamma+\omega_{1}$ Ownership Indicators $+\omega_{2}$ Policy Change Indicators $+\omega_{3}$ Bank-specific control variables $+\omega_{4}$ Time Trend variable + Error term

The utilised variables are explained below and are summarised in Table 2.

\section{Ownership indicators}

There are three types of bank ownership considered in this study: state-owned commercial banks (SOCB), private banks (JSB) and foreign joint-venture banks (FJVB). Private banks are chosen as the base case and the other two ownership indicators (SOCB and FJVB) are included in the models. The indicator SOCB is set equal to one, indicating state-owned banks and zero for other bank types. A similar explanation is for the case of FJVB. Table 2 provides details on the definition of all environmental variables used in this study. 
We also investigate the major policy changes which could potentially have an impact on Vietnam's banking sector in the post-WTO era. Four reform measures are employed to capture the effect of these policies on banking efficiency by ownership type.

(i) Business groups' participation in the banking sector (BG)

Several SOEs and private business groups were allowed by the government to participate in the banking sector and become the holding companies of JSBs. Subsequently, a complex set of cross-ownership relationships between industrial and banking entities were established. To consider this issue, an indicator (BG) is included in the model to capture JSBs which have at least 20 per cent of their total equity owned by SOEs and/or private business groups. BG is set to one for periods after business group participation.

\section{(ii) Privatisation of SOCBs $(P)$}

367 In the post-WTO period SOCBs were targeted for privatisation, but this process had to ensure that the government retained a predominant fraction of the bank's capital. Following agency theory we would expect state ownership to negatively influence the performance of banks, and that state-owned banks would become more efficient after privatisation (La Porta et al., 2002). An indicator (P) is added to the model to capture privatised banks and is set equal to one for periods after privatisation.

\section{(iii) Foreign strategic investment (FSI)}

374 Foreign investors could become involved in domestic banks by purchasing the equity of either SOCBs or JSBs, with the proportion of equity sold to foreign investors not exceeding 30 per cent of total capital. FSI indicates banks with foreign involvement and is set equal to one for periods after foreign investment in these banks. 
An indicator (RU) is utilised to identify thirteen rural JSBs that were permitted to transfer to urban banks and is set equal to one for periods after the bank has been transformed. The reform changes included in this study are commonly regarded as the major changes in the literature regarding the Vietnamese banking sector (e.g., NAEC, 2012; IMF, 2012; World Bank, 2014). Several other non-trivial events, such as the global financial crisis, coincided with our study period, however it has been shown in previous studies that they were not as important in the context of the Vietnamese banking sector as the reforms considered in this study (see Nguyen et al., 2014; Nguyen and Simioni, 2015; Nguyen et al., 2016).

\section{Control variables}

Several other variables were chosen to capture the impact of bank characteristics on efficiency, including the loan-to-asset ratio (LA) representing bank preference for traditional assets, the equity-to-asset ratio (EA) as a proxy for financial soundness and the log of total bank assets as a proxy for bank size (SIZE). To control for the effect of time, a time-trend variable (T) was also included, which takes the value 1 for 2005, 2 for 2006 and so on, to capture the evolving nature of efficiency. Tables 3-6 provide descriptive statistics on bank distribution, inputs, outputs and explanatory variables used in this study.

Table 3 shows the annual distribution of the banks by number for the whole sample as well as for each bank group. Table 3 indicates that joint-stock banks dominate the sample, making up approximately two thirds of the banks in each year. Tables 4 and 5 provide statistical descriptions of the above-mentioned variables. State-owned banks have the largest inputs and outputs and their assets are more concentrated in loans when compared to private and foreign and joint-venture banks. The results of Kruskal-Wallis rank tests, which are provided in

401 Table 5, confirm these differences between the three bank types. Specifically, stark differences in efficiency under both intermediation and operating approaches can be 
observed. The state-owned banks are the most efficient group as they have the lowest mean inefficiency values compared with JSBs and FJVBs counterparts under both approaches. Table 6 reveals the collinearity status between environmental variables. The results suggest that the privatisation indicator is highly correlated with the SOCB indicator, and that bank size is highly correlated with the SOCB indicator, the privatisation indicator, and the equity to asset and time trend variables.

<TABLES 2-6 ABOUT HERE >

\subsection{Regression results}

The output-oriented technical inefficiency estimates are regressed against the set of regressors identified previously. To test the stability of the models and provide robust conclusions, six different model specifications are presented under each approach in Table 7. Similar results were obtained from all six models under each approach and are discussed in detail below. ${ }^{5}$

\section{$<$ TABLE 7 ABOUT HERE $>$}

\section{Ownership and efficiency}

Using domestic private banks as the base case, the SOCB indicator is employed to compare the efficiency of state-owned banks relative to these banks. The FJVB indicator plays a similar role in the regression models presented in Table 7.

Under both the intermediation and operating approaches coefficients for the SOCB variable are negative across all five models that include this variable. The SOCB coefficients are also significant in models 3-5 indicating that publicly-owned banks are more efficient than domestic private-owned banks both in terms of services provided and profitability (see Table

\footnotetext{
${ }^{5}$ It is worth highlighting again that inefficiency values are used as the dependent variable; therefore a negative coefficient implies a positive (beneficial) impact on efficiency.
} 

owned banks. Firstly, these banks benefit from a scale effect as supported by the results for the SIZE coefficient for both the intermediation and operating approaches (see Table 7). The size of SOCBs, based on the mean value of total assets, is approximately 7 times larger than that of the JSBs (private banks), and 20 times larger than that of the FJVBs (see Table 5). Secondly, the positive impact of privatisation of a subset of SOCBs has improved the overall performance of the SOCBs relative to the JSBs and FJVBs (see Table 7).

The coefficients on the FJVB indicator are negative across the five models and significant in models 2 to 5 under the intermediation approach. This suggests a superior performance of foreign joint-venture banks in terms of providing loans and advances in comparison with their domestic private counterparts (JSBs). None of the coefficients are significant under the operating approach. The better performance of FJVBs under the intermediation approach can be explained by their superior technology and expertise, which offset their lack of experience in the local market. Moreover, FDI enterprises, which contribute 18\% of Vietnam's GDP, prefer to utilise the banking services provided by FJVBs rather than domestic banks due to their relationship with the parent banks of FJVBs in their home countries.

Business groups' participation in the banking sector (BG)

While the coefficients on the BG variable are insignificant under the intermediation approach they are significant and positive under the operating approach. This indicates that private banks with business group involvement underperformed when compared with the other banks from a profit efficiency perspective. This finding suggests that business groups participate in the banking sector in Vietnam as a way to secure their funding sources. However, this participation simultaneously undermines the operational (profitability) efficiency of these associate banks and the banking sector as a whole. 
450 The coefficients on the 'P' variable, indicating state-owned banks experiencing privatisation, 451 are found to be negative and highly significant across the different models and approaches. 452 This suggests that privatised banks outperformed other banks based on both the operating and 453 intermediation approaches. That is, the privatisation of state-owned banks improved both their service and operating efficiency despite their ongoing predominant state ownership. These results are consistent with that of Berger et al. (2009) for the case of China arising from WTO entry, but contradict the findings of Bonin et al. (2005b). Bonin et al. (2005b) argue that the partial privatisation of SOCBs, for the cases of Vietnam and China, cannot generate any performance improvement. This is because, as the dominant shareholder, the state is continuously in a strong position to run the banks, thereby reducing the likelihood of changes to corporate governance practices. Kraft et al. (2006) also state that a comprehensive privatisation of public banks, without sufficient changes to management, can reduce the performance of the banking industry. Our findings in the Vietnamese context do not lend support to this notion.

Foreign strategic investment (FSI)

The coefficients measuring the impact of foreign strategic investment on domestic private bank efficiency are found to be insignificant for both the intermediation and operating approaches, contrary to the findings of several studies in the literature including Berger et al. (2009). Berger et al. (2009) suggest that foreign involvement, even in terms of minority shareholding, is normally expected to have an unambiguously positive impact on banking performance. One may argue that the discriminatory measures in favour of state-owned banks in Vietnam are so significant that they offset traditional advantages arising from foreign investor strategic involvement in domestic private banks. Hence, unless such discriminatory measures are addressed, the efficiency benefits derivable from foreign investment in the 
banking system will be limited, as will be the willingness of foreign investors to invest in

475

476

477 domestic private banks. These results are certainly contrary to findings in the mainstream literature and suggest that the Vietnamese government needs to address this problem otherwise the benefits from foreign investment in domestic banks (expertise and capital) will be lost. The other factor is that minority foreign ownership will be insufficient in bringing about substantial changes to governance and management quality, due to the reluctance of majority domestic owners ${ }^{6}$ who have control of these JSBs in Vietnam. Only banks with majority foreign ownership (FJVB) are found to be more efficient than domestic private banks under the intermediation approach. Hence, the 30 per cent limit on foreign ownership of domestic bank equity should be reviewed based on these results.

\section{Transformed rural to urban JSBs (RU)}

The RU coefficients indicate that transformed JSBs from rural to urban banks are negatively and significantly associated with bank efficiency in all the models under both approaches. This outcome indicates that transformed banks are less efficient in terms of both their ability to provide intermediation services and generate profit when compared to their counterparts. They contribute negatively to overall banking sector efficiency in Vietnam.

There are two possible reasons for this. Firstly, their governance capability may have been inadequate given the increased range of their operations after becoming urban banks. Transformed banks were required to cover a significantly larger range of operations than they had done before. Their customer base and assets had increased substantially within a period of two or three years and many branches had opened nationwide, but this did not improve efficiency. The second potential reason is that insufficiently selective decisions by the SBV on awarding licences to rural banks resulted in a rapid growth of credit under inexperienced

\footnotetext{
${ }^{6}$ The reluctance to conduct significant changes of bank governance and management can be due to the cultural and institutional differences.
} 
bankers which led to increased risk taking and a failure to adequately diversify bank assets

498

499

500

501

502

503

504

505

506

507

508

509

510

511

512

513

514

515

516

517

518

519 and generate profits. In reality, many of the small transformed JSBs used the majority of their credit to purchase property and stocks. As a result, this risk-taking behaviour led to an accumulation of bad loans, substantially increased risk-related costs and contributed to a decline in private and overall banking sector efficiency.

\section{Control variables}

Loans-to-assets ratio (LA)

Under the intermediation approach we observe a positive relationship between the loans-toassets ratio and bank efficiency. This outcome is in line with the findings of Chortareas et al. (2012), and supports the argument that banks engaging in more traditional activities (transforming deposits into loans) are more efficient. This can be explained by the fact that an expansionary monetary policy was implemented to stimulate economic growth during the pre- and post-WTO periods in Vietnam, and the fact that loans represent the bulk of bank assets. Domestic banks were in a race to expand branches nationwide and attract deposits from households and corporations. Under human capital and physical resource constraints, banks maximised their capability to provide intermediation services and expected that the loans would enhance their profitability.

Under the operating approach the regression results show a negative relationship between the LA ratio and efficiency, so the profit-oriented efficiency of private banks with a high LA ratio actually declined. The LA ratio is a proxy for liquidity risk, which considers the cost of attracting deposits and borrowing. Based on the results from this study it can be argued that Vietnamese banks can improve their (profit-oriented) efficiencies by decreasing traditional assets (loans and advances) and increasing non-traditional assets (investments and securities). 
521 The equity-to-assets ratio acts as a proxy for the financial soundness of a bank (Gropp and 522 Heider, 2010; Fiordelisi et al., 2011). A bank with a higher EA ratio is safer in terms of 523 capital and is in a stronger position to deflect risks relating to equity losses. A positive 524 relationship between capital and efficiency, consistent with agency theory, is commonly 525 found in the literature (e.g., Fries and Taci, 2005; Fiordelisi et al., 2011). According to 526 Jeitschko and Jeung (2005) the managers of banks with less capital have a greater incentive to engage in moral hazard because they face less shareholder scrutiny when compared with 528 banks that have higher capital ratios. Berger and De Young (1997) also point out that those 529 banks reaching higher risk levels in the medium term have to employ more inputs to administer these higher risks, which results in declining efficiency and profitability. Regulators can also force banks to increase their capital and adequately disclose their riskrelated costs commensurate with the degree of risk assumed (Gropp and Heider, 2010).

533 All five models employed in this study using the intermediation approach produce insignificant results. This contrasts substantially with the operating approach, which produces significant results of a negative association between the EA ratio and the profit-oriented efficiency in all five models (see Table 7). This uncommonly negative relationship between capital and efficiency may be due to the weak regulatory and supervisory framework of the Vietnamese banking sector. Under this, risks, especially credit risks, are inadequately accounted for and as a result risk-related costs and equity are often underestimated. Subsequently, figures on bank profitability and equity are often not commensurate with the

541 level of risk (Laeven, 1999). Moreover, outdated Vietnamese accounting standards cannot 542 keep up with changes in the risk profile of banks (IMF, 2012). These factors implicitly stimulate banks to provide more intermediate services (especially loans) and obtain a higher 
rate of return. This cycle, repeated several times over, creates a negative relationship between capital and efficiency.

Bank size (SIZE)

547 The coefficient on bank size in model 1 of Table 7 is significant and negative under both the intermediation and the operating approach. ${ }^{7}$ These results suggest that larger banks exhibit greater intermediation (service-oriented) efficiency as well as operating (profit-oriented) efficiency. This aligns with other studies and supports the notion that economies of scale are beneficial in the banking sectors of transition and emerging economies (Bonin et al., 2005b; Berger et al., 2009).

Time trend (T)

554 The time trend coefficient indicates that banking efficiency increased between 2005 and 2015 under the intermediation approach but no significant result was found for this variable under

556 the operating approach. This is consistent with a rapid increase in credit and lending 557 intermediation undertaken by the banking sector during the period of this study and that this has been achieved along with increased efficiency.

\subsection{Tests for bank-fixed effects and selection effects of policy changes}

560 Although the above analysis provides substantial insights into the relationship between policy changes and Vietnamese bank efficiency by ownership type, it is important to note that relying solely on the double bootstrap DEA results can be inadequate without considering potential endogeneity concerns. This arises because banking reforms which impacted some banks and not others might be due to self-selection or omitted variable(s). In other words, banks may have been selected into the various reforms based on particular ex ante

\footnotetext{
${ }^{7}$ To avoid collinearity issues, the SIZE variable is not included in models (2) to (6) (mainly due to its high correlation with the SOCB and P indicators). In fact, when we tried to add Size in models (2) to (6) all the coefficients of the SOCB indicator become insignificant. Thus, it is only incorporated in model (1) where the ownership indicators and other policy change indicators are excluded.
} 
characteristics which may lead to bias in the measurement of the effects of the reforms on

567 efficiency levels. For example, foreign investors would select to invest in more promising JSBs based on pre-reform assessments of financial performance. Then the positive effects of foreign ownership on the efficiency of JSBs are not due to the participation of foreign investors but due to their selection based on ex ante characteristics. Therefore, in order to provide additional robustness to the results provided in Table 7, a generalised difference-indifferences model with multiple treatments is included in this and the subsequent sections. Despite this latter model being limited in its capacity to address time-variant unobservable variable concerns, it does reduce bias in the estimation of policy effects by controlling for time-invariant confounders.

To justify the inclusion of a two-way fixed effects model, both the Breusch and Pagan (1980) Lagrange Multiplier (LM) and Hausman (1978) chi square statistics were calculated for the intermediation and operating efficiency models. Firstly, the Breusch and Pagan (1980) LM statistic identifies the existence of dynamic heterogeneity in the model. By using a set of OLS residuals it tests the null hypothesis that group effects do not exist (Greene, 2003). Secondly, the Hausman (1978) chi square statistic tests the appropriateness of employing a fixed effects or least squares dummy variable (LSDV) model relative to a generalised least squares (GLS) specification. The Hausman (1978) chi square statistic tests the null hypothesis that individual effects are appropriately modelled through the implementation of a random effects estimator (Judge et al. 1985; Green, 2003). With respect to both intermediation efficiency (column 1) and operating efficiency (column 2) regressions in Table 8, a two-way fixed 587 effects regression is justified on the basis that both the Breusch and Pagan (1980) LM and 588 Hausman (1978) chi square statistics are rejected at the 5 per cent level. Both the intermediation and operating efficiency regressions produce substantially large Breusch- 
with all results statistically significant at the 5 per cent level. Thus, the results from the two tests support the use of two-way fixed effects in accounting for heterogeneity in the dataset and facilitating the analysis of treatment effects with respect to the policy variables.

\subsection{Two-way fixed effects regression: policy effects after controlling for time-invariant covariates}

The generalised difference-in-differences (DID) (two-way fixed effects with multiple treatments) regression is a common method used in policy evaluation in the face of multiple treatments over a number of time periods (see Imbens and Wooldridge, 2002; Bertrand et al., 2004; Angrist and Pishke, 2009). This study incorporates the empirical framework established by Bertrand et al., (2004) and Hansen (2007) as a basis for conducting differencein-differences with multiple treatments. At the individual level the equation employed in this study is established as:

$\delta_{h g t}=\alpha+\beta d_{h g t}+\gamma z_{h g t}+\theta_{g}+\lambda_{t}+\varepsilon_{\mathrm{hgt}}$

Here, $h$ is an index for individual banks $(h=1, \ldots, N), g$ represents the bank groups (including privatised banks; banks with foreign strategic investment; banks with business participation and urban-rural transformed banks) and $t$ is the index for time $(t=1, \ldots, T) . \delta_{h g t}$ denotes the bank performance measure (either intermediation or operating efficiency). $\alpha$ is a constant, $d_{h g t}$ is a policy change indicator that indicates bank $h$ belongs to group $g$ in year $t, z_{h g t}$ is a vector of individual-specific control variables (which includes LA and EA ratios) and $\varepsilon_{h g t}$ is the error term. Bank fixed effects are denoted as $\theta_{g}$ and a full set of year effects are captured in $\lambda_{t}$. In addition, robust standard errors are clustered at the bank-level.

The treatment effect of each policy is identified by their respective $\beta$ coefficient, which captures the average treatment effect for each policy. The underlying intuition for this result is that the year effects $\left(\lambda_{t}\right)$ provide a control for the post-regulation dummy, and bank fixed 
effects $\left(\theta_{g}\right)$ act as the control for the treatment dummy for each policy intervention. The use of year and bank fixed effects therefore create the conditions for the measurement of policy effects independent of time-invariant confounders.

The two-way fixed effects regressions in Table 8 supplement the main analysis in Table 7, and isolate 'within-bank' variation through the implementation of both bank and year fixed effects. For the purposes of consistency the directionality and interpretation of results provided in Table 8 are comparable to those in Table 7. This method is appropriate for testing the robustness of the main results provided in Table 7, given that we focus on the impact of several reform measures instituted by the Vietnamese government over a ten year period. By isolating the 'within' bank variation over time it reduces the likelihood of bias in the estimation of treatment effects brought about by features of the banking system which may have had a direct impact on efficiency. Given that this method controls for observed and unobserved time-invariant heterogeneity in regressions, variables representing bank ownership type are not included in the regression analysis in Table 8.

\section{$<$ TABLE 8 ABOUT HERE $>$}

While the results from sub-section 6.3 point to no significant difference between banks with business participation and other banks (see Table 7) under the intermediation approach, the coefficients on the BG variable are significantly negative in model 1 of Table 8 . Consequently, after controlling for time-invariant characteristics, the results in Table 8 indicate that the participation of business groups in private banks increases the intermediation efficiency of these banks over the long term. The reason for this is that these groups are contributors to bank equity, which in turn enables them to attract more deposits for lending. A substantial portion of these loans, however, are allocated to the subsidiaries of these groups, which raises concerns regarding the associated increase in credit risk. A high level of 
credit risk can lead to high loan-loss provisioning costs and lower profitability/operating efficiency but this issue is found to be insignificant in our regression models where timeinvariant effects are not accounted for (see Table 8). The results in Table 8 support a positive and dynamic influence of privatisation on the operating efficiency of state-owned banks. The policy of privatisation has forced privatised banks to increase their management quality, adhere to more rigorous banking standards, and increase their capital. In the long term, these banks are expected to operate more efficiently, consistent with their increased commercialisation. The results in Table 8 are also consistent with those in Table 7 in that privatised banks outperform the others under the operating approach.

Private banks that transformed from rural to urban have experienced a decline of intermediation efficiency between 2005 and 2015 (see Table 8). This result is consistent with the findings in Table 7 and indicates that transformed banks have a significant and negative effect on intermediation efficiency. Although the policy of transformation encouraged these banks to broaden their geographical reach and the scope of their intermediating services, the quality of their management has not improved in line with this growth. The end result is a decline in intermediation efficiency. Transforming rural into urban banks has contributed unambiguously to a negative impact on bank intermediation efficiency. Table 8 also supports the result in Table 7, which suggest that foreign strategic investment has not significantly impacted the intermediation and operating efficiency of domestic private banks.

\section{Conclusion}

The reform of banking sectors has diverged amongst transition economies and each transition can be categorised into either partial or full liberalisation. While the latter advocates a fair and competitive market for all banks, the former can reflect a desire by government to control and employ the sector as a tool to serve its political purposes and, in doing so, favour one 
type of bank over another. This study has examined the impact of reform measures on bank efficiency in the context of Vietnam's transition economy.

665 Using data for Vietnamese banks covering the pre- and post-WTO period (2005-2015) and applying the DEA double bootstrapping methodology to measure banking efficiency, under the intermediation and operating approaches, it was found that the state-owned bank group was the most efficient. In contrast, and contrary to the mainstream view in the literature, joint-stock banks were found to be the least efficient.

In terms of the impact of reform measures on banking efficiency the results show that transforming rural to urban banks contributed negatively to the intermediation efficiency performance of private banks and the overall banking sector under both the DEA and DID approaches. Negative results for bank operating efficiency were also observed under DEA. The privatisation of SOCBs was found to improve both their intermediation and operating efficiency using DEA, but was found to only improve their operating efficiency using DID. Foreign strategic investment exerted an insignificant impact on both private bank intermediation and operating efficiency using both DEA and DID. While the participation of business groups in the domestic banking sector improved intermediation efficiency but had no significant impact on operating efficiency using DID, using DEA indicated that they exerted a negative impact on operating efficiency and had no significant impact on intermediation efficiency. Under the DEA model, bank size positively impacts intermediation and operating efficiency and, paradoxically, a negative relationship between capital and operating efficiency is also found in this study.

Based on these findings, several key policies can be recommended to improve the efficiency of Vietnamese banks. First, the privatisation of SOCBs can result in a positive and dynamic effect on the operating efficiency of banks, and possibly also intermediation efficiency. 
Hence, one may argue that it can and should be applied more widely in the sector. Second, it

688

689

690

691

692

693

694

695

696

697

698

699

700

701

702

703

704

705

706

707

708

709 is found that transformed JSBs from rural to urban banks are less efficient under the intermediation and operating approach using DEA, while this is only found to be the case for intermediation efficiency using DID. Since most of the transformed JSBs are small banks (their mean value of total assets is equivalent to approximately one third of the mean value for the overall Vietnamese banking system $)^{8}$, one way of enhancing their efficiency may be to increase their size through either forced merger or acquisition. This is consistent with the results from DEA which suggest that there are benefits to be gained from economies of scale (SIZE) in the banking sector in terms of both intermediation and operating efficiency. Policymakers should, therefore, actively encourage consolidation of the banking sector through mergers and acquisitions, with transformed JSBs being an important priority. Other small and inefficient banks should be considered to take part in this process as well, regardless of their ownership types.

Third, foreign strategic investment (up to 30\% of bank equity) has not significantly impacted the efficiency of domestic banks and the reasons for this need to be studied in more detail. This could arise due to the benefits of foreign investment being nullified by remaining discriminatory measures and barriers which need to be addressed. In addition, the limit of $30 \%$ foreign ownership of domestic bank equity should be increased. Fourth, the paradoxical negative relationship between the equity-to-asset ratio and operating efficiency found under DEA is indicative of a weak Vietnamese banking regulatory and supervisory framework. Hence policymakers need to improve the quality of the regulatory and supervisory framework of the banking system, and in doing so this may improve the management of risk in the sector and require banks to be more accountable for incurring risk-related costs.

\footnotetext{
${ }^{8}$ According to our calculations, the mean value of total assets for transformed JSBs is $18,388,534$ million VND while this value is 63,257,994 million VND for all Vietnamese banks over the period 2005-2015.
} 
710 Acknowledgment

711 We would like to thank Professor Jun-Koo Kang, the Editor-in-Chief, and anonymous

712 reviewers for their insightful comments, which have led to substantial improvements in the

713 paper. Any remaining errors are the authors’.

714 
Table 1: Structure of the Vietnamese banking sector by ownership type, 2007, 2011 and 2016

\begin{tabular}{|c|c|c|c|c|c|c|c|c|c|}
\hline & \multicolumn{3}{|c|}{ December 2007} & \multicolumn{3}{|c|}{ December 2011} & \multicolumn{3}{|c|}{ December 2016} \\
\hline & $\begin{array}{l}\text { Total Assets } \\
\text { (in VND } \\
\text { trillions) }\end{array}$ & $\begin{array}{l}\text { Share of Total } \\
\text { Assets }\end{array}$ & $\begin{array}{l}\text { Share of } \\
\text { GDP }\end{array}$ & $\begin{array}{l}\text { Total Assets } \\
\text { (in VND } \\
\text { trillions) }\end{array}$ & $\begin{array}{l}\text { Share of Total } \\
\text { Assets }\end{array}$ & $\begin{array}{l}\text { Share of } \\
\text { GDP }\end{array}$ & $\begin{array}{l}\text { Total Assets } \\
\text { (in VND } \\
\text { trillions) }\end{array}$ & $\begin{array}{l}\text { Share of Total } \\
\text { Assets }\end{array}$ & $\begin{array}{l}\text { Share of } \\
\text { GDP }\end{array}$ \\
\hline $\begin{array}{l}\text { State-owned } \\
\text { commercial banks }\end{array}$ & 931.5 & 54 & 81 & 1912.3 & 40 & 69 & 3861.9 & 48 & 104 \\
\hline Joint-stock banks & 597.7 & 34 & 52 & 2285.8 & 48 & 82 & 3422.8 & 42 & 92 \\
\hline $\begin{array}{l}\text { Foreign and joint- } \\
\text { venture banks }\end{array}$ & 204 & 12 & 18 & 552.4 & 12 & 20 & 828.3 & 10 & 22 \\
\hline All banks & 1733.2 & 100 & 152 & 4750.5 & 100 & 171 & 8113 & 100 & 218 \\
\hline
\end{tabular}

Sources: World Bank (2014) and the SBV online resources. 
Table 2: Summary of the employed regression variables

\begin{tabular}{|c|c|c|}
\hline Variables & Abbreviations & Descriptions \\
\hline \multicolumn{3}{|l|}{ Bank performance measures } \\
\hline Intermediation technical efficiency & ITE & $\begin{array}{l}\text { Obtained using DEA with three inputs (labour cost, fixed assets and deposits) and two outputs (loans and other } \\
\text { assets). }\end{array}$ \\
\hline Operating technical efficiency & OTE & $\begin{array}{l}\text { Obtained using DEA with two inputs (interest expenses and non-interest expenses) and two outputs (interest income } \\
\text { and non-interest income). }\end{array}$ \\
\hline \multicolumn{3}{|l|}{ Ownership indicators } \\
\hline State-owned banks & SOCB & Indicator indicating state-owned banks. Equal to one for all periods a bank is state-owned. \\
\hline Foreign and joint-venture banks & FJVB & $\begin{array}{l}\text { Indicator indicating foreign and joint-venture banks. Equal to one for all periods if a bank is a foreign or joint venture } \\
\text { bank. }\end{array}$ \\
\hline \multicolumn{3}{|l|}{ Policy change indicators } \\
\hline SOCB privatisation & $\mathrm{P}$ & $\begin{array}{l}\text { Indicator indicating SOCBs that experienced privatisation between } 2005 \text { and } 2015 \text {. Equal to one for the periods after } \\
\text { the privatisation of a bank. }\end{array}$ \\
\hline Foreign capital participation & FSI & $\begin{array}{l}\text { Indicator indicating a bank sold a minor proportion of its equity (not exceeding } 30 \text { per cent) to foreign investors. } \\
\text { Equal to one for the periods after foreign capital investment in the bank. If an SOCB went through foreign capital } \\
\text { participation and privatisation the variable will be set to zero due to the fact that foreign capital participation is one of } \\
\text { many measures during the process of privatising state-owned banks. }\end{array}$ \\
\hline $\begin{array}{l}\text { Business group participation in } \\
\text { JSBs }\end{array}$ & BG & $\begin{array}{l}\text { Indicator indicating JSBs have experienced equity participation by SOEs and/or private business groups. Equal to one } \\
\text { for the periods after business group participation in a bank. }\end{array}$ \\
\hline Rural-urban transformation & RU & $\begin{array}{l}\text { Indicator indicating JSBs that transformed from rural to urban banks. Equal to one for the periods after transformation } \\
\text { of a bank. }\end{array}$ \\
\hline \multicolumn{3}{|l|}{ Control variables } \\
\hline Loans-to-assets ratio & LA & The ratio of loans to assets measures the preference for traditional banking activities. \\
\hline Equity-to-assets ratio & EA & The ratio of equity to assets measures the financial soundness of a bank. \\
\hline Size & SIZE & The log form of total bank assets is used as a proxy for bank size \\
\hline Time trend & $\mathrm{T}$ & Time trend variable $(2005=1,2006=2, \ldots, 2015=11)$ \\
\hline
\end{tabular}


Table 3: Annual distribution of the banks for the whole sample and each bank group

\begin{tabular}{|c|c|c|c|c|}
\hline Year & No. of JSB & No. of SOCB & No. of FJVB & Total \\
\hline 2007 & 19 & 5 & 2 & 26 \\
\hline 2009 & 25 & 5 & 3 & 33 \\
\hline 2010 & 25 & 5 & 4 & 34 \\
\hline 2011 & 25 & 5 & 6 & 36 \\
\hline 2014 & 21 & 4 & 5 & 30 \\
\hline 2015 & 18 & 4 & 4 & 26 \\
\hline Total & 227 & 52 & 38 & 317 \\
\hline
\end{tabular}

Note: the last row presents the sums of bank-year observations when the sample is pooled. 
Table 4: Statistical description of the variables for all banks

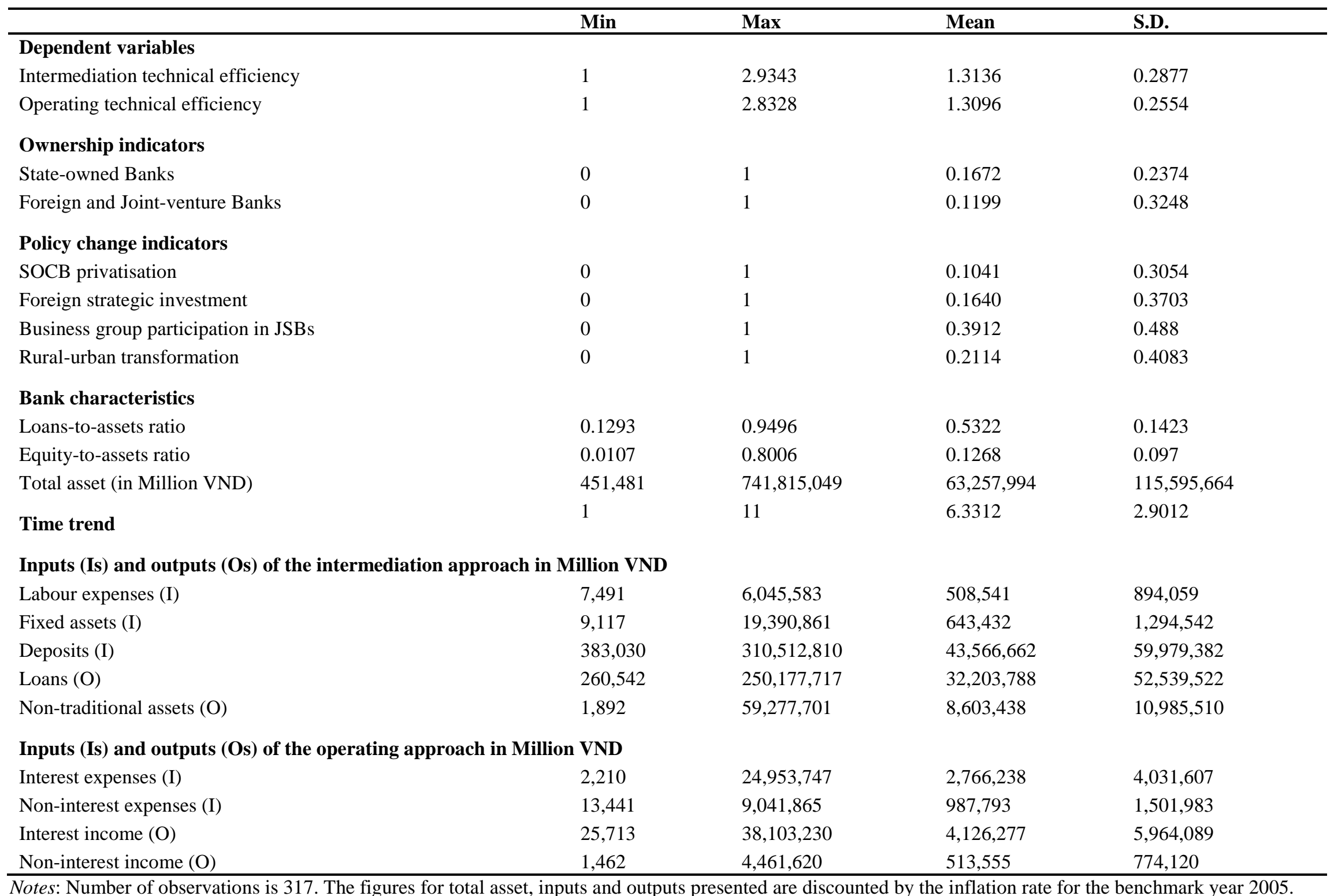


Table 5: Statistical description of the variables for each bank group

\begin{tabular}{|c|c|c|c|c|c|c|c|}
\hline & \multicolumn{2}{|c|}{$\begin{array}{l}\text { Private banks } \\
\text { (227 observations) }\end{array}$} & \multicolumn{2}{|c|}{$\begin{array}{l}\text { State-owned banks } \\
\text { (52 observations) }\end{array}$} & \multicolumn{2}{|c|}{$\begin{array}{l}\text { Foreign and Joint- } \\
\text { venture banks } \\
\text { ( } 38 \text { observations) }\end{array}$} & \multirow{2}{*}{ 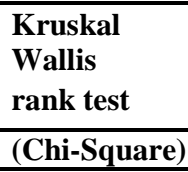 } \\
\hline & Mean & Median & Mean & Median & Mean & Median & \\
\hline Intermediation technical efficiency & 1.3742 & 1.3538 & 1.1479 & 1.0620 & 1.1882 & 1.0881 & $38.1051^{* * *}$ \\
\hline Operating technical efficiency & 1.3475 & 1.3169 & 1.1666 & 1.0990 & 1.2804 & 1.2620 & $32.8920 * * *$ \\
\hline Loans-to-assets ratio & 0.5039 & 0.5015 & 0.6453 & 0.6575 & 0.5553 & 0.5385 & $46.5628^{* * *}$ \\
\hline Equity-to-assets ratio & 0.1294 & 0.1021 & 0.0591 & 0.0599 & 0.2239 & 0.1848 & $115.9908 * * *$ \\
\hline Total asset (in Million VND) & $33,304,604$ & $17,163,207$ & $230,109,366$ & $167,926,627$ & $11,502,526$ & $5,977,193$ & $98.3674 * * *$ \\
\hline Time trend & 6.304 & 6 & 5.7692 & 6 & 7.2632 & 7.5 & \\
\hline \multicolumn{8}{|c|}{ Inputs (Is) and outputs (Os) of the intermediation approach in Million VND } \\
\hline Labour expenses (I) & 253,218 & 162,623 & $1,886,298$ & $1,830,568$ & 148,410 & 105,901 & $85.0420 * * *$ \\
\hline Deposits (I) & $24,675,203$ & $20,705,710$ & $151,982,038$ & $160,560,882$ & $8,060,390$ & $5,972,747$ & $101.4054^{* * *}$ \\
\hline Loans (O) & $14,825,513$ & $12,003,522$ & $127,633,721$ & $138,217,241$ & $5,427,787$ & $5,477,247$ & $97.0019 * * *$ \\
\hline Non-traditional assets $(\mathrm{O})$ & $5,835,428$ & $3,416,682$ & $25,858,500$ & $25,416,975$ & $1,526,464$ & 492,980 & $88.8194^{* * *}$ \\
\hline \multicolumn{8}{|c|}{ Inputs (Is) and outputs (Os) of the operating approach in Million VND } \\
\hline Interest expenses (I) & $1,684,662$ & $1,354,768$ & $9,330,964$ & $9,734,419$ & 243,927 & 259,173 & $124.8364 * * *$ \\
\hline Non-interest expenses (I) & 546,348 & 395,523 & $3,461,134$ & $3,534,419$ & 240,274 & 145,301 & $86.2677^{* * *}$ \\
\hline Interest income $(\mathrm{O})$ & $2,442,316$ & $2,073,037$ & $14,057,935$ & $14,665,189$ & 595,040 & 497,192 & $107.2766^{* * *}$ \\
\hline Non-interest income (O) & 295,779 & 169,883 & $1,728,833$ & $1,761,397$ & 151,467 & 99,393 & $68.7230 * * *$ \\
\hline
\end{tabular}

Notes: The figures for total assets, inputs and outputs presented are discounted by the inflation rate for the benchmark year 2005. ${ }^{* * *}$ indicates a statistically significant difference between groups at the 1 per cent level. Kruskal-Wallis tests show that intermediation efficiency, operating efficiency, explanatory variables (loan-to-equity ratio, equity-to-asset ratio and total asset), outputs (loans, non-traditional assets, interest income, non-interest income) and inputs (labour expenses, fixed assets, deposits, interest expenses, non-interest expenses) are different across the three bank categories. 
Table 6: Correlation matrix of environmental variables

\begin{tabular}{|c|c|c|c|c|c|c|c|c|c|c|}
\hline & SOCB & FJVB & $\mathrm{P}$ & FSI & $B G$ & RU & LA & EA & SIZE & $\mathrm{T}$ \\
\hline SOCB & 1.0000 & & & & & & & & & \\
\hline FJVB & -0.1393 & 1.0000 & & & & & & & & \\
\hline $\mathrm{P}$ & 0.7608 & -0.1258 & 1.0000 & & & & & & & \\
\hline FSI & -0.1985 & -0.1635 & -0.1510 & 1.0000 & & & & & & \\
\hline BG & -0.3591 & -0.2958 & -0.2732 & -0.3551 & 1.0000 & & & & & \\
\hline RU & -0.2320 & -0.1911 & -0.1765 & -0.2293 & 0.3609 & 1.0000 & & & & \\
\hline LA & 0.3457 & 0.0598 & 0.2396 & -0.1373 & -0.2411 & -0.0733 & 1.0000 & & & \\
\hline EA & -0.3092 & 0.3695 & -0.2230 & -0.1388 & 0.0402 & 0.2475 & -0.0575 & 1.0000 & & \\
\hline SIZE & 0.5605 & -0.3029 & 0.4979 & 0.1888 & -0.2386 & -0.2957 & 0.1787 & -0.5505 & 1.0000 & \\
\hline $\mathrm{T}$ & -0.0774 & 0.1185 & -0.0389 & 0.0816 & 0.0578 & 0.0874 & -0.0679 & 0.0337 & 0.4239 & 1.0000 \\
\hline
\end{tabular}

Notes: SOCB is state-owned banks; FJVB is foreign-joint venture bank: P is privatisation indicator; FSI is foreign strategic investment: BG: business group participation; RU is rural-urban transformation; LA is loan to asset ratio; EA is equity to asset ratio; SIZE is log of total assets; $\mathrm{T}$ is time trend variable. 
Table 7: Regressing environmental variables on bank performance measures

\begin{tabular}{|c|c|c|c|c|c|c|c|c|c|c|c|c|}
\hline & \multicolumn{6}{|c|}{ Intermediation technical efficiency ( 317 observations) } & \multicolumn{6}{|c|}{ Operating technical efficiency (317 observations) } \\
\hline & 1 & 2 & 3 & 4 & 5 & 6 & 1 & 2 & 3 & 4 & 5 & 6 \\
\hline \multirow[t]{2}{*}{ Constant term } & $4.3714^{* * *}$ & $2.2911 * * *$ & $2.2841^{* * *}$ & $2.2995 * * *$ & $2.2967 * * *$ & $2.2461^{* * *}$ & $3.5285^{* * *}$ & $0.9467^{* * *}$ & $0.9668^{* * *}$ & $0.8458^{* * *}$ & $0.958^{* * *}$ & $0.9412^{* * *}$ \\
\hline & $(0.3197)$ & $(0.1184)$ & $(0.1233)$ & $(0.1276)$ & $(0.1210)$ & $(0.1310)$ & $(0.3554)$ & $(0.1564)$ & $(0.1598)$ & $(0.1645)$ & $(0.1500)$ & $(0.1621)$ \\
\hline \multicolumn{13}{|l|}{ Ownership } \\
\hline \multirow[t]{2}{*}{ State-owned banks, SOCB } & & -0.1847 & $-0.3791 * * *$ & $-0.3933 * * *$ & $-0.3401 * * *$ & -0.0993 & & -0.1008 & $-0.5396 * * *$ & $-0.4307 * * *$ & $-0.4336 * * *$ & -0.0229 \\
\hline & & $(0.1349)$ & $(0.1059)$ & $(0.1065)$ & $(0.1000)$ & $(0.1402)$ & & $(0.1328)$ & $(0.1258)$ & $(0.1246)$ & $(0.1146)$ & $(0.1354)$ \\
\hline \multirow[t]{2}{*}{ Foreign and Joint-venture banks, FJVB } & & $-0.2066^{*}$ & $-0.1994 *$ & $-0.2156 * *$ & $-0.1066^{*}$ & -0.0531 & & -0.1131 & -0.1426 & -0.0356 & 0.0085 & 0.0436 \\
\hline & & $(0.0968)$ & $(0.0938)$ & $(0.0981)$ & $(0.0936)$ & $(0.1079)$ & & $(0.0945)$ & $(0.0942)$ & $(0.0997)$ & $(0.0964)$ & $(0.1088)$ \\
\hline \multicolumn{13}{|l|}{ Policy Change Indicators } \\
\hline \multirow[t]{2}{*}{ Privatisation Indicator, $\mathrm{P}$} & & $-0.3938 * *$ & & & & $-0.3642 * *$ & & $-1.0137 * * *$ & & & & $-0.9642 * * *$ \\
\hline & & $(0.1883)$ & & & & $(0.1783)$ & & $(0.2680)$ & & & & $(0.2513)$ \\
\hline \multirow[t]{2}{*}{ Foreign Strategic Investment Indicator, FSI } & & & 0.0393 & & & 0.1309 & & & -0.177 & & & -0.0349 \\
\hline & & & $(0.0646)$ & & & $(0.0867)$ & & & $(0.0902)$ & & & $(0.1070)$ \\
\hline \multirow[t]{2}{*}{ Business Participation Indicator, BG } & & & & -0.011 & & 0.0104 & & & & $0.1373^{* *}$ & & $0.0778^{*}$ \\
\hline & & & & $(0.0562)$ & & $(0.0681)$ & & & & $(0.0665)$ & & $(0.0369)$ \\
\hline \multirow[t]{2}{*}{ Rural-Urban transformation Indicator, RU } & & & & & $0.1931^{* * *}$ & $0.2329 * * *$ & & & & & $0.2454 * * *$ & $0.2160 * * *$ \\
\hline & & & & & $(0.0607)$ & $(0.0671)$ & & & & & $(0.0715)$ & $(0.0743)$ \\
\hline \multicolumn{13}{|l|}{ Control Variables } \\
\hline \multirow[t]{2}{*}{ Loan to Asset ratio, LA } & $-1.3968^{* * *}$ & $-1.4135^{* * *}$ & $-1.4011^{* * *}$ & $-1.4042^{* * *}$ & $-1.4019 * * *$ & $-1.3864 * * *$ & $0.4260 * *$ & $0.5676^{* *}$ & $0.5942 * *$ & $0.6502 * * *$ & $0.5741^{* *}$ & $0.5494 * *$ \\
\hline & $(0.1806)$ & (0.1973) & $(0.2101)$ & (0.2129) & $(0.2091)$ & $(0.1968)$ & $(0.1842)$ & $(0.2172)$ & $(0.2203)$ & $(0.2158)$ & $(0.2117)$ & (0.2024) \\
\hline \multirow[t]{2}{*}{ Equity to Asset ratio, EA } & & 0.1546 & 0.1546 & 0.1400 & -0.1440 & -0.1511 & & $0.9006^{* * *}$ & $0.7703^{* * *}$ & $0.8257 * * *$ & $0.4904 *$ & $0.5423^{* *}$ \\
\hline & & $(0.2744)$ & $(0.2668)$ & $(0.2619)$ & $(0.2767)$ & $(0.2802)$ & & $(0.2870)$ & $(0.2968)$ & $(0.2975)$ & $(0.3027)$ & $(0.2944)$ \\
\hline \multirow[t]{2}{*}{ SIZE } & $-0.1375^{* * *}$ & & & & & & $-0.1507 * * *$ & & & & & \\
\hline & $(0.0186)$ & & & & & & $(0.0229)$ & & & & & \\
\hline \multirow[t]{2}{*}{ Time Trend, $\mathrm{T}$} & & $-0.0298 * * *$ & $-0.0306 * * *$ & $-0.0300 * * *$ & $-0.0343^{* * *}$ & $-0.0354 * * *$ & & -0.0126 & -0.0099 & -0.0137 & -0.0176 & -0.0179 \\
\hline & & $(0.0093)$ & $(0.0093)$ & $(0.0090)$ & $(0.0090)$ & $(0.0092)$ & & $(0.0100)$ & $(0.0102)$ & $(0.0100)$ & (0.0099) & $(0.0102)$ \\
\hline
\end{tabular}

Note: The coefficients with ${ }^{*},{ }^{* *}$ and ${ }^{* * *}$ are significant at 10,5 and 1 per cent levels, respectively. Standard errors at the bank-level are provided in parentheses. 
Table 8: Tests for bank-fixed effects and selection effects of policy changes

\begin{tabular}{|c|c|c|}
\hline & (1) & (2) \\
\hline & Intermediation Efficiency Scores & Operating Efficiency Scores \\
\hline Constant term & $\begin{array}{l}1.8461 * * * \\
(0.1851)\end{array}$ & $\begin{array}{l}1.2192 * * * \\
(0.1749)\end{array}$ \\
\hline \multicolumn{3}{|l|}{ Policy Change Indicators } \\
\hline Privatisation Indicator, $\mathrm{P}$ & $\begin{array}{l}0.0090 \\
(0.0826)\end{array}$ & $\begin{array}{l}-0.1041^{* *} \\
(0.0498)\end{array}$ \\
\hline Foreign Strategic Investment Indicator, FSI & $\begin{array}{l}0.1349 \\
(0.1499)\end{array}$ & $\begin{array}{l}-0.0688 \\
(0.0670)\end{array}$ \\
\hline Business Participation Indicator, BG & $\begin{array}{l}-0.4996 * * \\
(0.2339)\end{array}$ & $\begin{array}{l}-0.0234 \\
(0.0328)\end{array}$ \\
\hline Rural - Urban Transformation Indicator, RU & $\begin{array}{l}0.5633^{* * *} \\
(0.1672)\end{array}$ & $\begin{array}{l}0.0287 \\
(0.0513)\end{array}$ \\
\hline \multicolumn{3}{|l|}{ Control Variables } \\
\hline Loan to Asset ratio, LA & $\begin{array}{l}-0.9100^{* * * *} \\
(0.2898)\end{array}$ & $\begin{array}{l}0.3999 \\
(0.3183)\end{array}$ \\
\hline Equity to Asset ratio, EA & $\begin{array}{l}-0.3290 \\
(0.2576)\end{array}$ & $\begin{array}{l}-0.2761 \\
(0.3455)\end{array}$ \\
\hline Bank Fixed Effects & Yes & Yes \\
\hline Year Effects & Yes & Yes \\
\hline R-Squared (within) & 0.3207 & 0.1563 \\
\hline Number of observations & 317 & 317 \\
\hline
\end{tabular}

Notes: The coefficients with **, or *** are significant at 5 , and 1 per cent levels, respectively. Cluster-robust standard errors at the bank-level are provided in parentheses. All regressions include bank and year fixed effects. Intermediation efficiency is the dependent variable for model (1) and operation efficiency is the dependent variable for model (2). All 'policy change indicators' are set to one for the period after the introduction of the policy for banks in the treatment group, and zero otherwise. Control variables include the Loan to Assets ratio and the Equity to Assets ratio. Due to collinearity issues in the two-way fixed effects model the ownership variables on bank type JSB, SOCB and FJVB were not included in the analysis. The regressions provided in Table 7 were re-estimated with the use of Driscoll and Kraay (1998) standard errors. This additional analysis was completed to assess whether or not issues associated with cross-sectional dependence were present in the sample. Driscoll and Kraay (1998) standard errors account for potential herding behaviour amongst banks and spillover effects which otherwise would not be captured with the use of cluster-robust standard errors. We found no material difference between the two standard error estimations, and, therefore, the additional regressions are not disclosed in the tabulated result. 


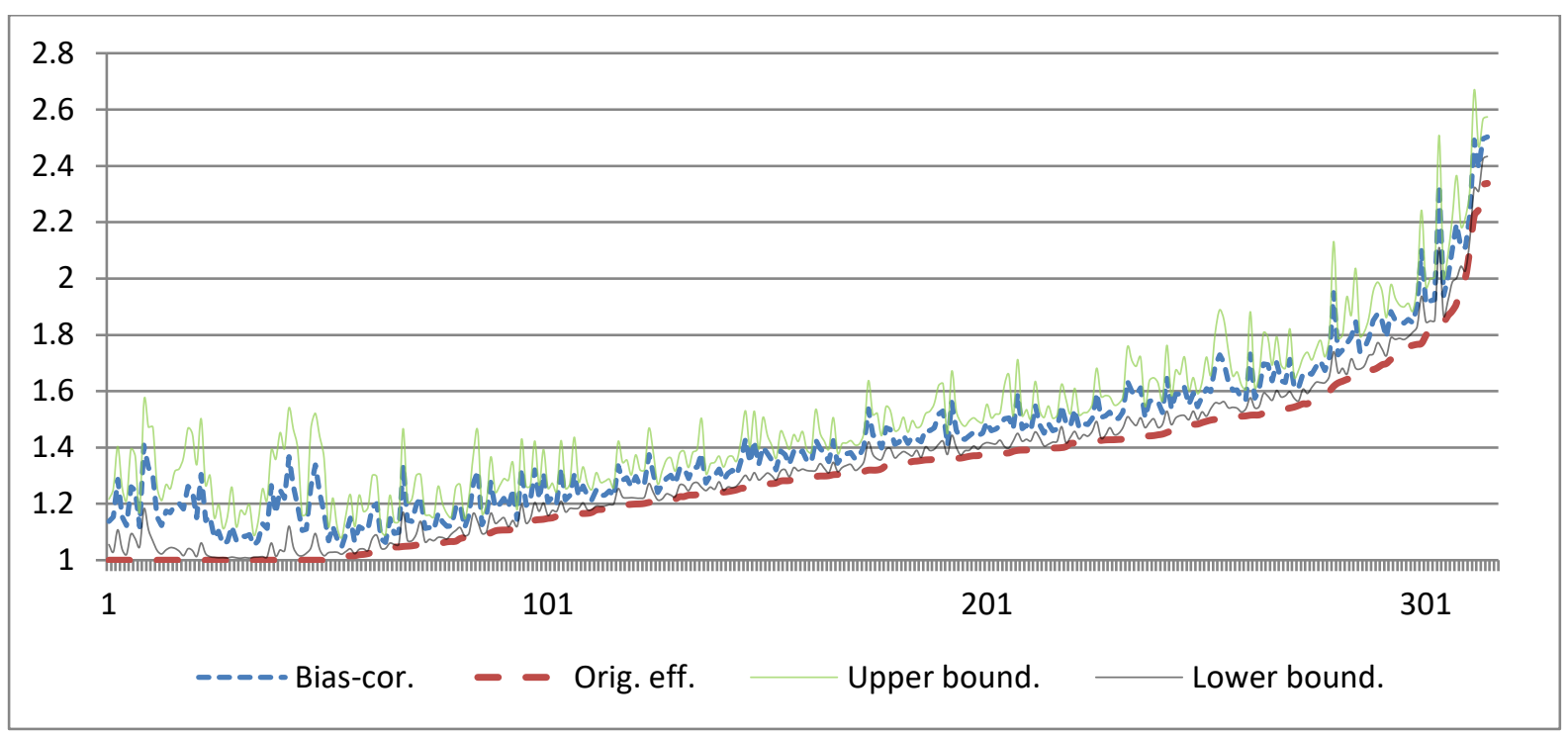

Figure 1: Confidence intervals and point estimates for technical efficiencies under the intermediation approach

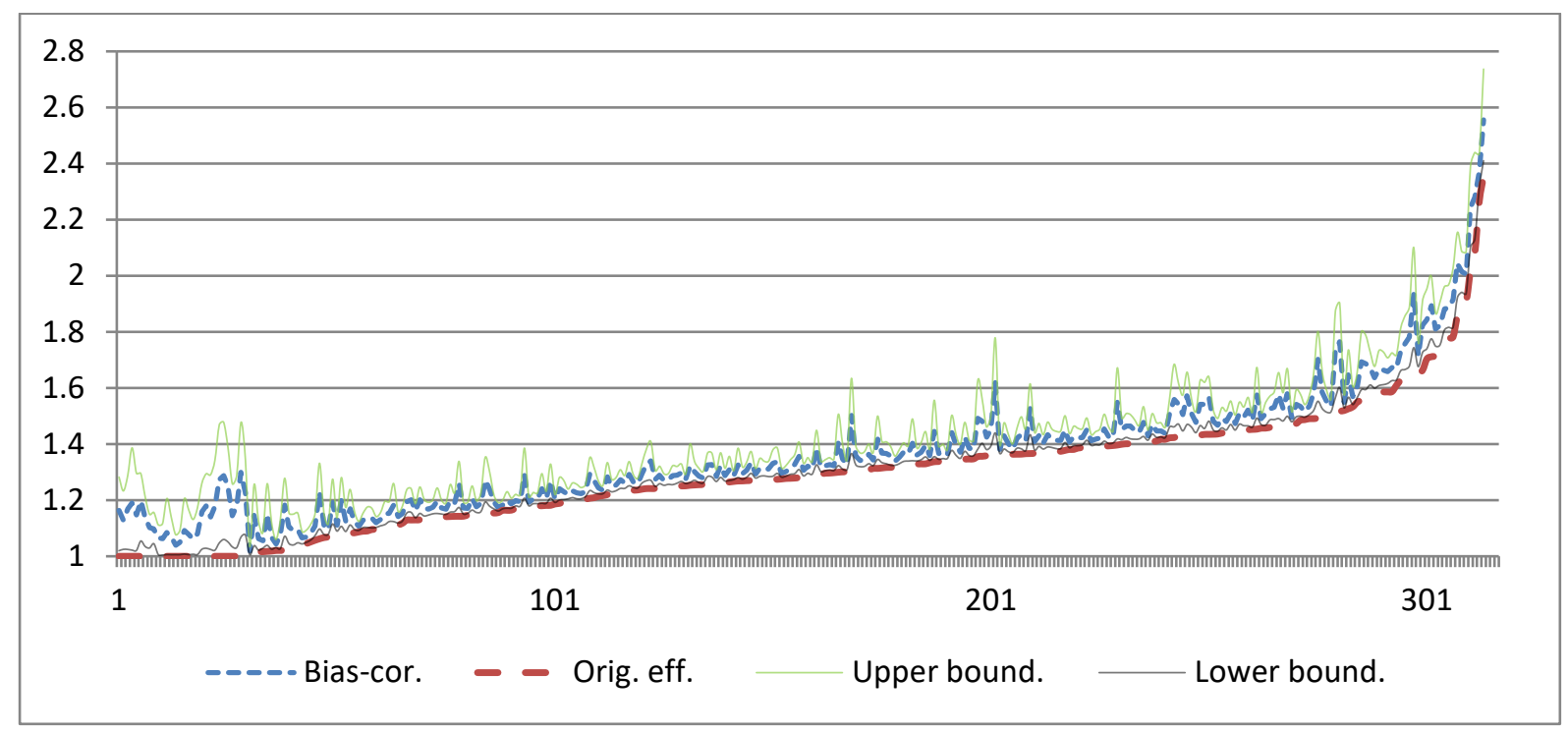

Figure 2: Confidence intervals and point estimates for technical efficiencies under the operating approach 


\section{Appendix A: Double-bootstrap two-stage DEA algorithm}

1) Use the original data in $\mathcal{P}_{n}=\left\{x_{k}, y_{k}\right\}_{k=1}^{n}$ to compute $\hat{\delta}_{k}=\delta\left(x_{k}, y_{k} \backslash \widehat{\wp}\right) \forall k=1, \ldots, n$ by DEA, using equation (4)

2) Use the method of maximum likelihood to obtain an estimate $\hat{\beta}$ of $\beta$ as well as an estimate $\hat{\sigma}_{\varepsilon}$ of $\sigma_{\varepsilon}$ in the truncated regression of $\hat{\delta}_{k}$ on $z_{k}$ using $m<n$ observations when $\hat{\delta}_{k}>1$

3) Loop over the next four steps (3.1-3.4) $L_{1}$ times to obtain $n$ sets of bootstrap estimates $\mathcal{B}_{k}=$ $\left\{\hat{\delta}_{k b}^{*}\right\}_{b=1}^{L_{1}}$ :

3.1) For each $k=1, \ldots, n$ draw $\varepsilon_{k}$ from the $N\left(0, \hat{\sigma}_{\varepsilon}^{2}\right)$ distribution with left-truncation at $(1-$ $\left.z_{k} \hat{\beta}\right)$

3.2) Again for each $k=1, \ldots, n$, compute $\delta_{k}^{*}=z_{k} \hat{\beta}+\varepsilon_{k}$

3.3) Set $x_{k}^{*}=x_{k}, y_{k}^{*}=y_{k} \hat{\delta}_{k} / \delta_{k}^{*}$ for all $k=1, \ldots, n$

3.4) Using equation (4) to compute $\hat{\delta}_{k}^{*}=\delta\left(x_{k}, y_{k}\right) \backslash \widehat{\wp}^{*} \forall k=1, \ldots, n$ where $\widehat{\wp}^{*}$ is obtained by replacing $\left(x_{k}, y_{k}\right)$ in equation (3) with $\left(x_{k}^{*}, y_{k}^{*}\right)$ from step (3.3)

4) For each $k=1, \ldots, n$ compute the bias-corrected estimator $\hat{\delta}_{k}$ using the bootstrap estimates in $\mathcal{B}_{k}$ obtained in step (3.4) and the original estimate $\hat{\delta}_{k}$, where $\hat{\delta}_{k}=2 \hat{\delta}_{k}-m e a n \hat{\delta}_{k b}^{*}$

5) Use the method of maximum likelihood to estimate the truncated regression of $\hat{\delta}_{k}$ on $z_{k}$, yielding estimate $\hat{\hat{\beta}}, \hat{\hat{\sigma}}$

6) Loop over the next three steps (6.1-6.3) $L_{2}$ times to obtain a set of bootstrap estimates $\mathcal{C}=$ $\left\{\left(\hat{\hat{\beta}}^{*}, \hat{\hat{\sigma}}_{\varepsilon}^{*}\right)_{b}\right\}_{b=1}^{L_{2}}$ :

6.1) For each $k=1, \ldots, n$ draw $\varepsilon_{k}$ from the $N(0, \hat{\hat{\sigma}})$ distribution with left-truncation at $\left(1-z_{k} \hat{\hat{\beta}}\right)$

6.2) Again for each $k=1, \ldots, n$, compute $\delta_{k}^{* *}=z_{k} \hat{\hat{\beta}}+\varepsilon_{k}$

6.3) Use the method of maximum likelihood to estimate the truncated regression of $\delta_{k}^{* *}$ on $z_{k}$, yielding estimate $\left(\hat{\hat{\beta}}^{*}, \hat{\hat{\sigma}}_{\varepsilon}^{*}\right)$

7) Use the bootstrap values in $\mathcal{C}$ and the original estimate $\hat{\hat{\beta}}, \hat{\hat{\sigma}}$ to construct estimated confidence intervals for each element of $\beta$ and $\sigma_{\mathcal{\varepsilon}}$. 


\section{References}

Andrianova, S., Demetriades, P., \& Shortland, A. (2012). 'Government ownership of banks, institutions and economic growth'. Economica, 79, pp. 449-469.

Angrist, J. D. and Pischke, J. S. (2008). Mostly Harmless Econometrics: An Empiricist’s Companion, Princeton University Press.

Arjomandi, A., Valadkhani, A. and O’Brien, M. (2014). ‘Analysing banks' intermediation and operational performance using the Hicks-Moorsteen TFP index: The case of Iran', Research in International Business and Finance, 30, pp. 111-125.

Belanès, A., Ftitic, Z. and Regaïegd, R. (2015). 'What can we learn about Islamic banks efficiency under the subprime crisis? Evidence from GCC Region', Pacific-Basin Finance Journal, 33, pp. 81-92.

Belousova, V., Karminsky, A. and Kozyr, I. (2018). 'Bank ownership and profit efficiency of Russian banks', Bank of Finland Institute for Economies in Transition, Discussion paper Number 5.

Beresford, M. (2008). 'Doi Moi in review: The challenges of building market socialism in Vietnam', Journal of Contemporary Asia, 38, pp. 221-243.

Berger, A. N., Bonime, S. D., Covitz, D. M., \& Hancock, D. (2000). 'Why are bank profits so persistent? The roles of product market competition, informational opacity, and regional/macroeconomic shocks'. Journal of Banking \& Finance, 24, pp. 1203-1235.

Berger, A. N. and De Young, R. (1997). 'Problem loans and cost efficiency in commercial banks', Journal of Banking and Finance, 21, pp. 849-870.

Berger, A. N., Hasan, I. and Zhou, M. (2009). 'Bank ownership and efficiency in China: What will happen in the world's largest nation?’, Journal of Banking and Finance, 33, pp. 113-130.

Berger, A. N. and Mester, L. J. (2003). 'Explaining the dramatic changes in performance of US banks: Technological change, deregulation, and dynamic changes in competition, Journal of Financial Intermediation, 12, pp. 57-95.

Bertrand, M., Duflo, E. and Mullainathan, S. (2004). 'How much should we trust differences-indifferences estimates?’, The Quarterly Journal of Economics, 119, pp. 249-275.

Bonin, J. P. and Schnabel, I. (2011). 'The great transformation: From government-owned to foreigncontrolled banking sectors', Economics of Transition, 19, pp. 397-405.

Bonin, J. P., Hasan, I. and Wachtel, P. (2005a). 'Bank performance, efficiency and ownership in transition countries’, Journal of Banking and Finance, 29, pp. 31-53.

Bonin, J. P., Hasan, I. and Wachtel, P. (2005b). 'Privatization matters: Bank efficiency in transition countries’, Journal of Banking and Finance, 29, pp. 2155-2178.

Borovicka, J. (2007). 'Banking Efficiency and Foreign Ownership in Transition: Is There Evidence of a Cream-Skimming Effect?’, Financial Stability Report, Oesterreichische National bank (Austrian Central Bank), 13, pp 68-82.

Breusch, T. S. and Pagan, A. R. (1980). 'The Lagrange Multiplier Test and its Applications to Model Specification in Econometrics’, Review of Economic Studies, 47(1), pp. 239-253.

Brissimis, S. N., Delis, M. D. and Papanikolaou, N. I. (2008). 'Exploring the nexus between banking sector reform and performance: Evidence from newly acceded EU countries', Journal of Banking and Finance, 32, pp. 2674-83.

Charnes, A., Cooper, W. W. and Rhodes, E. (1978). 'Measuring the efficiency of decision making units’, European Journal of Operational Research, 2, pp. 429-444.

Chen, Y. and Wang, Y. (2015), 'The efficiency of China's banking industry and the determinants', International Economic Journal, 29, 4, pp. 631-653. 
Chiu, C. R., Chiu, Y. H., Chen, Y. C. and Fang, C. L. (2016). 'Exploring the source of metafrontier in-efficiency for various bank types in the two-stage network system with undesirable output', Pacific-Basin Finance Journal, 36, pp. 1-13.

Chortareas, G. E., Girardone, C. and Ventouri, A. (2012). 'Financial freedom and bank efficiency: Evidence from the European Union', Journal of Banking and Finance, 37, pp. 1223-1231.

Driscoll, J. C. and Kraay, A. C. (1998). 'Consistent covariance matrix estimation with spatially dependent panel data', Review of Economics and Statistics, 80, pp. 549-560.

Fang, Y., Hasan, I. and Marton, K. (2011). 'Bank efficiency in South-Eastern Europe', Economics of Transition, 19, pp. 495-520.

Farrell, M.J. (1957). 'The Measurement of Productive Efficiency', Journal of the Royal Statistical Society, 120, pp. 253-281.

Fiordelisi, F., Marques-Ibanez, D. and Molyneux, P. (2011). 'Efficiency and risk in European banking', Journal of Banking and Finance, 35, pp. 1315-1326.

Fries, S. and Taci, A. (2005). 'Cost efficiency of banks in transition: Evidence from 289 banks in 15 post-communist countries', Journal of Banking and Finance, 29, pp. 55-81.

Greene, W.H. (2003). Econometric Analysis, 5th ed. Prentice Hall, Upper Saddle River, New Jersey.

Golovan, S., Karminsky, A., \& Peresetsky, A. (2008). 'Cost efficiency of Russian banks. Models with risk factors’. Ekonomika i matematicheskiye metody, 44, pp. 28-38.

Grigorian, D. A., and V. Manole. 2006. "Determinants of commercial bank performance in transition: an application of data envelopment analysis”. Comparative Economic Studies, 48(3), pp. 497522.

Gropp, R. and Heider, F. (2010). 'The determinants of bank capital structure', Review of Finance, 14, pp. 587-622.

Hansen, C. B. (2007). 'Generalized least squares inference in panel and multilevel models with serial correlation and fixed effects’, Journal of Econometrics, 140(2), pp. 670-694.

Harvie, C. and Hoa, T.V. (1997). Vietnam's Reforms and Economic Growth, Houndmills, Basingstoke, Hampshire: MacMillan Press Ltd.

Hausman, J. A. (1978). 'Specification tests in Econometrics’, Econometrica, 46, pp. 1251-1271.

Hasan, I., \& Marton, K. (2003). 'Development and efficiency of the banking sector in a transitional economy: Hungarian experience'. Journal of Banking \& Finance, 27, pp. 2249-2271.

Hasan, I., Koetter, M and Wedow, M. (2009). 'Regional growth and finance in Europe: Is there a quality effect of bank efficiency?', Journal of Banking and Finance, 33, pp. 1413-1422.

Havrylchyk, O. (2006). 'Efficiency of the Polish banking industry: Foreign versus domestic banks', Journal of Banking and Finance, 30, pp. 1975-1996.

Imbens, G. W. and Wooldridge, J. M. (2009). 'Recent developments in the Econometrics of program evaluation’, Journal of Economic Literature, 47, pp. 5-86.

IMF (2012). 'Vietnam 2012 Article IV Consultation', IMF country report, No. 12/165. International Monetary Fund, Washington, D.C.

Jeitschko, T. D. and Jeung, S. D. (2005). 'Incentives for risk-taking in banking - A unified approach', Journal of Banking and Finance, 29, pp. 759-777.

Jemric, I., and Vujcic, B. (2002). 'Efficiency of banks in Croatia: A DEA approach.' Comparative Economic Studies, 44(2-3), pp. 169-193.

Jiang, C., Yao, S. and Zhang, Z. (2009). 'The effects of governance changes on bank efficiency in China: A stochastic distance function approach’, China Economic Review, 20, pp. 717-731. 
Judge, G. (1985). The Theory and Practice of Econometrics, 2nd ed., Wiley.

Karas, A., Schoors, K. and Weill, L. (2010). 'Are private banks more efficient than public banks?', Economics of Transition, 18, pp. 209-244.

Kneip, A., Park, B.U. and Simar, L. (1998). 'A note on the convergence of nonparametric DEA estimators for production efficiency scores’, Econometric Theory, 14, pp. 783-793.

Kneip, A., Simar, L. and Wilson, P.W. (2008). Asymptotics and consistent bootstraps for DEA estimators in non-parametric frontier models, Econometric Theory, 24, pp. 1663-1697.

Koivu, T. (2002). 'Do efficient banking sectors accelerate economic growth in transition countries?', Working papers by Bank of Finland Institute for Economies in Transition.Series DP, BOFIT Discussion Papers, No. 14.

Koetter, M., and M. Wedow (2010). 'Finance and growth in a bank-based economy: Is it quantity or quality that matters?', Journal of International Money and Finance, 29, pp. 1529-1545.

Koutsomanoli-Filippaki, A., Margaritis, D. and Staikouras, C. (2009). 'Efficiency and productivity growth in the banking industry of Central and Eastern Europe', Journal of Banking and Finance, 33(3), pp. 557-567.

Kovsted, J., Rand, J. and Tarp, F. (2005). From Monobank to Commercial Banking: Financial sector reforms in Vietnam, Nordic Institute of Asian Studies Press.

Kraft, E., Hofler, R. and Payne, J. (2006). 'Privatization, foreign bank entry and bank efficiency in Croatia: A Fourier-flexible function stochastic cost frontier analysis', Applied Economics, 38, pp. 2075-2088.

La Porta, R., Lopez-De-Silanes, F. and Shleifer, A. (2002). 'Government ownership of banks', The Journal of Finance, 57, pp. 265-301.

Laeven, L. (1999). 'Risk and efficiency in East Asian banks', World Bank Policy Research Working Paper No. 2255, The World Bank.

Leightner, J. E. and Lovell, C. (1998). 'The impact of financial liberalization on the performance of Thai banks', Journal of Economics and Business, 50, pp. 115-131.

Leung, M. K. and Chan, R.Y.K. (2006). 'Are Foreign Banks Sure Winners in Post-WTO China?', Business Horizons, 49, pp. 221-234, 2006.

Levine, R. (2001). 'International financial liberalization and economic growth.' Review of International Economics, 9, pp. 688-702.

Mamonov, M., and Vernikov, A. (2017). 'Bank ownership and cost efficiency: New empirical evidence from Russia', Economic Systems, 41, pp. 305-319.

NAEC (2012). 'From Macroeconomic Turbulent to Restructuring', Economic Commission Working Paper, Vietnam National Assembly, Hanoi.

Nikiel, E.M. and Opiela, T.P. (2002). 'Customer type and bank efficiency in Poland: Implications for emerging market banking', Contemporary Economic Policy, 20, pp. 255 - 271.

Nguyen, K.M., Giang, T.L. and Nguyen, V.H. (2012). 'Efficiency and super-efficiency of commercial banks in Vietnam: Performances and determinants', Asia-Pacific Journal of Operational Research, 30, pp. 1-19.

Nguyen, T. P. T., Roca, E. and Sharma, P. (2014). 'How efficient is the banking system of Asia's next economic dragon? Evidence from rolling DEA windows', Applied Economics, 46, pp. 1-20.

Nguyen, P. A. and Simioni, M. (2015). 'Productivity and efficiency of Vietnamese banking system: New evidence using Färe-Primont index analysis’, Applied Economics, 47, pp. 4395-4407. 
Nguyen, T. P. T, Nghiem, S. H., Roca, E. and Sharma, P. (2016). 'Bank reforms and efficiency in Vietnamese banks: Evidence based on SFA and DEA', Applied Economics, 48, pp. 28222835.

Nguyen, V. H. (2007). 'Measuring Efficiency of Vietnamese Commercial Banks: An Application of Data Envelopment Analysis', in Nguyen, K. M. and Giang, L. T. (eds), Technical Efficiency and Productivity Growth in Vietnam, Hanoi: Publishing Houser of Social Labour Press.

Oh, S. N. (1999). 'Financial deepening in the banking sector-Vietnam. Rising to the Challenge in Asia: A Study of Financial Markets - The Socialist Republic of Viet Nam', Asian Development Bank Working Paper, Manila.

Pincus, J. (2009). 'Vietnam: Sustaining growth in difficult times', ASEAN Economic Bulletin, 26, pp. $11-24$.

Rosman, R., Wahab, N. A. and Zainol, Z. (2014). 'Efficiency of Islamic banks during the financial crisis: An analysis of Middle Eastern and Asian countries', Pacific-Basin Finance Journal, 28, pp. 76-90.

Salim, R., Arjomandi, A., \& Dakpo, K. H. (2017). Banks’ efficiency and credit risk analysis using byproduction approach: the case of Iranian banks. Applied Economics, 49, pp. 2974-2988.

Salim, R., Arjomandi, A. and Seufert, J. H. (2016). 'Does corporate governance affect Australian banks' performance?', Journal of International Financial Markets, Institutions and Money, 43, pp. 113-125.

Shephard R. W. (1970). Theory of Cost and Production Functions. Princeton University Press Princeton.

Simar, L. and Wilson, P. W. (1998). 'Sensitivity analysis of efficiency scores: How to bootstrap in nonparametric frontier models', Management Science, 44, pp. 49-61.

Simar, L. and Wilson, P. W. (2007). 'Estimation and inference in two-stage, semi-parametric models of production processes', Journal of Econometrics, 136, pp. 31-64.

Styrin, K. (2005). 'What explains differences in efficiency across Russian banks'. Economics Education and Research Consortium, pp. 1-29.

Tochkov, K. and Nenovsky, N. (2009). 'Efficiency of commercial banks in Bulgaria in the wake of EU accession’. Bulgarian National Bank Discussion paper no DP/75/.

Vernikov, A (2012). 'The impact of state-controlled banks on the Russian banking sector', Eurasian Geography and Economics, 53, pp. 250-266.

Weill, L. (2003). 'Banking efficiency in transition economies', Economics of Transition, 11(3), pp.569-592.

World Bank (2014). 'Financial Sector Assessment', World Bank Vietnam Report, No. 92618, Washington, D.C.

$\mathrm{Xu}, \mathrm{Y}$. (2011). 'Towards a more accurate measure of foreign bank entry and its impact on domestic banking performance: The case of China', Journal of Banking and Finance, 35, pp. 886-901.

Yildirim, H.S., Philippatos, G. (2007), 'Efficiency of banks: Recent evidence from the transition economies of Europe 1993-2000', European Journal of Finance, 13, pp.123-143

Zajc, P. (2006). 'A Comparative Study of Bank Efficiency in Central and Eastern Europe: The Role of Foreign Ownership', International Finance Review, 6, pp. 117-156.

Zhang, X. T. and Wang, Y. (2014). 'Production efficiency of Chinese banks: a revisit', Managerial Finance, 40, 10, pp.969-986. 